Jurnal Bisnis dan Manajemen, Volume 21, No. 2, September 2020, p. 156-165

\title{
IMPACT OF INCOME, CONSUMPTION, SAVING, AND NUMBER OF ZAKAT MANAGEMENT ORGANIZATIONS ON THE ZAKAT FUND COLLECTION
}

\author{
Deru R Indika ${ }^{1}$, Sarah Nur Fauziyyah Himawan ${ }^{2}$, Egi Arvian Firmansyah ${ }^{3}$ \\ 1,2,3 Universitas Padjadjaran, Indonesia
}

\begin{abstract}
The good and responsible use of zakat funds can benefit the entire community. As the Muslim-majority country, Indonesia had the zakat potential of around 217 trillion rupiahs (in 2017). However, the realization of zakat fund collection was only $1.8 \%$ or around 4.1 trillion rupiahs. The same thing also happened primarily in the province of West Java, which could only collect zakat funds of around $2 \%$ of its entire zakat potential of 17.6 trillion rupiahs. This research aims at analyzing the factors affecting the collection of zakat funds in the cities of West Java. The data used in this research is the secondary data (from 2011-2017), acquired from the Central Bureau of Statistics (BPS), The Ministry of Religion, and BAZNAS (Nasional Zakat Agency). The data is analyzed using the Multiple Linear Regression Model and Generalized Least Squares (GLS) or Random Effect Method. The results of this research show that income, consumption, and the number of Zakat Management Organizations have a positive and significant effect on the zakat fund collection while saving has a negative and insignificant effect on zakat fund collection in West Java.
\end{abstract}

Keywords: zakat funds, income, consumption, saving, zakat institutions, generalized least square

\section{DAMPAK TINGKAT PENDAPATAN, KONSUMSI, TABUNGAN DAN JUMLAH ORGANISASI PENGELOLA ZAKAT TERHADAP PENGHIMPUNAN DANA ZAKAT}

\begin{abstract}
ABSTRAK
Pendayagunaan dana zakat yang baik dan bertanggungjawab dapat bermanfaat bagi seluruh masyarakat. Indonesia sebagai negara yang mayoritas berpenduduk muslim mempunyai potensi zakat mencapai 217 triliun rupiah (tahun 2017) realisasi pengumpulan dana zakatnya hanya 1,8\% yaitu sebesar 4.1 triliun rupiah. Hal yang sama juga terjadi di provinsi Jawa Barat yang baru bisa mengumpulkan dana zakatnya 2\% dari potensi zakatnya yang mencapai 17.6 triliun rupiah. Tujuan dari penelitian ini adalah untuk menganalisis faktor-faktor yang mempengaruhi penghimpunan dana zakat di seluruh kota di Jawa Barat. Data yang digunakan dalam penelitian ini adalah data sekunder periode 2001 - 2017. Data yang digunakan peneliti diambil dari Badan Pusat Statistika (BPS), Kementrian Agama serta Badan Amil Zakat Nasional (BAZNAS). Data dianalisis dengan menggunakan model regresi linear berganda dan metode Generalized Least Square (GLS) atau Random Effect. Hasil penelitian ini menunjukkan bahwa peningkatan jumlah pendapatan, pengeluaran konsumsi serta Organisasi Pengelola Zakat (OPZ) memiliki pengaruh positif dan signifikan terhadap peningkatan penghimpunan dana zakat sedangkan tingkat tabungan memiliki pengaruh negatif dan tidak signifikan terhadap penghimpunan dana zakat di Jawa Barat.
\end{abstract}

Kata-kata Kunci: dana zakat, pendapatan, konsumsi, tabungan, organisasi pengelola zakat, generalized least square

\footnotetext{
${ }^{1}$ Korespondensi: Deru R Indika, S.E., MBA. Fakultas Ekonomi dan Bisnis, Universitas Padjadjaran. Jln. Dipati Ukur No. 35 Bandung, 40135, Jawa Barat, Indonesia. Email: deru.indika@unpad.ac.id
}

Submitted: July 2020, Accepted: September 2020, Published: September 2020

ISSN: 1412 - 3681 (printed), ISSN: 2442 - 4617 (online), Website: http://journal.feb.unpad.ac.id/index.php/jbm 
Jurnal Bisnis dan Manajemen, Volume 21, No. 2, September 2020, p. 156-165

\section{INTRODUCTION}

In the concept of Islamic economics, it is explained that zakat is the main instrument of redistribution and income distribution for realizing prosperity. Zakat is not only a transfer of wealth from the rich to the poor but also a source of state financial income in developing the welfare of Muslims in various sectors, such as infrastructure, education, and science development. In practice, however, the economic empowerment of Muslims through the implementation of zakat still faces many obstacles. The primary cause of this problem lies in the Muslims themselves. The implementation of zakat in the Muslim community is the lack of an adequate understanding of zakat, such as the amount of zakat, nishab, and the time to pay certain zakat. Hence, the implementation of zakat is highly dependent on each individual (Hakim, 2016).

There are still many Muslims, especially in Indonesia, who have not paid zakat. Of the total population, Muslims make up to 80 percent, and the potential of zakat was around 217 trillion rupiahs (Saubani, 2018). However, in 2017, the number of recorded zakat was only about 4.1 trillion rupiahs (BAZNAS, 2018). It is caused by the low awareness of Muslims to pay zakat and the preference of paying zakat directly to families or informal zakat managers. Hence, the record of zakat funds may not be entirely representative (Fitriyah, 2017). So, the realization of zakat collection in Indonesia is still far from the ideal.
This phenomenon also prevails in West Java, the province with the most population in Indonesia. In West Java Province, with a Muslim population of 45 million people, around 50 percent of them are muzakki (an Islamic term for zakat payers). Its zakat revenue potential was around 17.6 trillion rupiahs or around $7 \%$ of the national scale. However, BAZNAS could only raise zakat funds in West Java of around 500 billion rupiahs, far from the potential (Nurulliah, 2017). In other words, only about 2 percent of the West Javanese Muslims have fulfilled their zakat obligation through formal zakat institutions.

The most common zakat paid by Muslims is the zakat al-fitr paid every Ramadan month. Other types of zakat that should be paid by Muslims are zakat al-maal or zakat on assets, such as income zakat, zakat from farming, and gold. Zakat al-maal is taken from wealth, both in terms of traditional contexts such as agricultural products, mineral resources, gold, jewelry, cash, business, and livestock, as well as in modern contexts, such as income from assets, salaries, and securities (Canggih, Fikriyah, \& Yasin, 2017). As shown in Figure 1, the knowledge of Muslims about the obligation to pay zakat almaal is still minimal, as evidenced by the difference in the number of collected funds from zakat al-fitr and zakat al-maal. Ideally, the difference between these two types of zakat should not be significant. 
Jurnal Bisnis dan Manajemen, Volume 21, No. 2, September 2020, p. 156-165

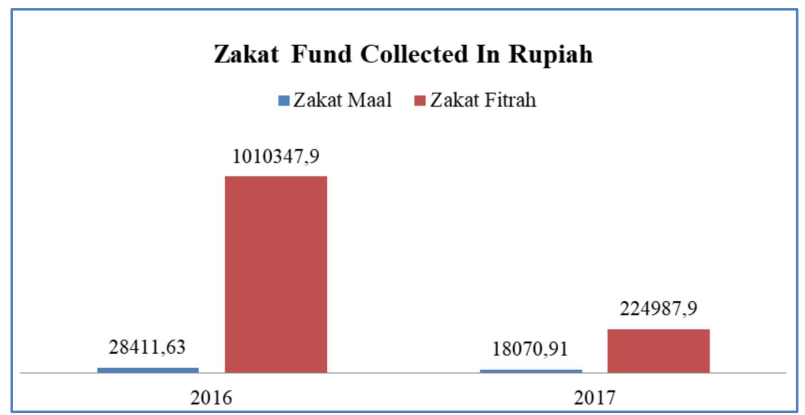

Figure 1. Zakat Maal and Zakat al-Fitr Collected in West Java

Source: Central Bureau of Statistics of West Java 2016 - 2018 (processed data)

In addition to the awareness, some other things affect the decision of Muslims to pay zakat. Those factors include income level, consumption expenditure, amount of savings (Noviarita, 2015), and the number of zakat management organization (ZMO) available around them (Kusmanto, 2014). An active role of ZMO in promoting zakat collection service also affects the intention of the muzakki to pay zakat (Mubarok \& Fanani, 2014). The issue of zakat is not limited to the collection, but also how the zakat is distributed so that the existence of ZMO becomes an essential pillar in realizing people's welfare (Manurung, 2013).

It can be seen from Figure 2, where the growth of zakat collection in 2017 began to slow down when compared to the growth in 2016, which was only $13.1 \%$. Later, it increased in 2018 by $20.63 \%$. The increase in the amount of zakat collection is inseparable from the increasing public trust in BAZNAS. BAZNAS continues to develop innovations with the zakat digitization approach to facilitate zakat payments. With better service facilities, the zakat collection will increase every year

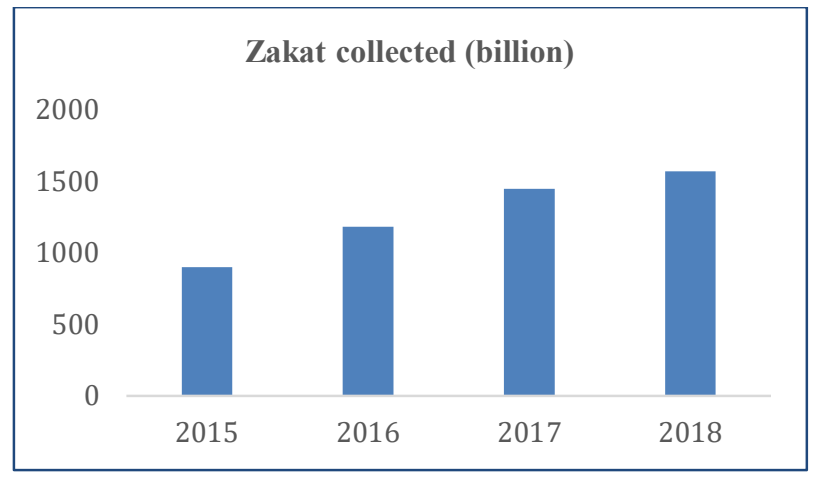

Figure 2. Zakat Collected by BAZNAS (2015-2019)

Those factors are essential to note because they affect the decision to pay zakat and determine the amount of zakat payment. Zakat is not only charged from fixed income but also nonfixed income, such as bonuses, honoraria, and other types of service income (MUI, 2003). The central problem of zakat in West Java, including in all of its cities, is the low amount of zakat collection, as shown by the low percentage of the collected amount compared to its potential. To see the root of this problem, this present study analyzes the effect of income, consumption, savings, and the number of ZMO on the collection of zakat funds.

\section{LITERATURE REVIEW}

In the macroeconomic approach, specifically in the variable of consumption expenditure, savings, and investment, zakat aggregately plays a significant role. So, it can be an indicator of the macroeconomic variable. In addition to a part of 
Jurnal Bisnis dan Manajemen, Volume 21, No. 2, September 2020, p. 156-165

religious obligation, zakat contains socioeconomic responsibilities for creating income redistribution between the rich and the poor (Noviarita, 2015).

Household consumption decisions have a considerable influence on the overall behavior of the economy, both in the short and long term. In the short run, consumption fluctuations have a significant influence on economic fluctuations. In the long run, household consumption decisions affect other macroeconomic variables. The current level of public consumption is influenced by the consumption of the previous period, disposable income of the current period, and the disposable income of the previous period (Persaulian, et al., 2013). Zakat has an influence on three macro indicators, namely aggregate consumption, aggregate investment, and aggregate supply. The injection of zakat funds will increase consumption and reduce savings (BAZNAS, 2019). the increase in the level of consumption is an indicator of improvement in the people's economy. With the increase in people's purchasing ability, as one of the public expenditure posts, zakat should also increase, especially since zakat is an obligation for Muslims.

Zakat collection also depends on the number of zakat institutions. Some said that the growing number of zakat institutions had not shown a substantial result in terms of zakat collection since the majority of people are reluctant to pay zakat through zakat institutions because of religiosity, location, service, and trust (Daulay \& Lubis, 2015). A negative image also arises because zakat collection organizations are considered affiliated with certain political parties and religious institutions with negative images.

Trust in ZMOs can be built if the zakat institution is able to build public trust if it is transparent in its management, especially in terms of financial disclosure to their stakeholders (Aziz \& Anim, 2019).

Furthermore, the ZMOs do not yet have an accurate database of mustahiq and possess an image that they have poor performance (Mubarok \& Fanani, 2014). They play a crucial role since the distributed zakat funds play an essential role in eradicating poverty in society (Senadjki, Nachef \& Rusli, 2015).

\section{METHODS}

This present study uses a descriptive quantitative approach to attain an overview of the processed data, primarily about the influence and relationship among the variables. The analysis employed in this study is a panel data regression, used to determine the relationship between several independent variables with one dependent variable.

Panel data (pooled data) is a regression analysis based on panel data (a combination of time series and cross-sections) to observe the relationship between one dependent variable with one or more independent variables (Pangestika, 2015). 
Jurnal Bisnis dan Manajemen, Volume 21, No. 2, September 2020, p. 156-165

According to Kuncoro (2011), some advantages that can be obtained using panel data estimates are a higher number of observations and more variations between different units according to particular space and time. Besides, Widarjono (2007) explained that panel data estimates provide an advantage for research in terms of a high number of observations, increasing the degree of freedom. The combination of cross-section and time-series data can overcome problems that occur when there are problems with variable removal.

This present study uses secondary data consisting of the reports on the amount of consumption, savings, public income, and reports on the number of ZMO in West Java. The data are obtained from the Central Statistics Agency (BPS), the Ministry of Religion, and BAZNAS. This research uses the annual scale data from 2012 to 2017.

The sampling technique used in this study is a saturated sampling technique, which is a sampling technique allowing all members of the population to be used as samples (Sugiyono, 2018). A saturated sampling is conducted if the population is relatively small, i.e., less than 30 people. Thus, all districts or cities in West Java are samples in this research, consisting of 18 districts and nine cities. Data processing of this study uses Microsoft Excel 2010 and EViews version 9 software.
Nachrowi \& Usman (2006) explained the econometric equation model of panel data regression as follows:

$$
\begin{aligned}
& \text { Where: } \\
& \text { Yit }=\text { dependent variable } \\
& \text { Xit }=\text { independent variable } \\
& \mathrm{i} \quad=\text { entity } \mathrm{i} \\
& \mathrm{t} \quad=\text { period } \mathrm{t}
\end{aligned}
$$$$
\text { Yit }=\alpha+\beta 1 \text { X1 it }+\beta 2 \text { X2it }+\ldots+\beta \text { nXnit }+ \text { eit }
$$

In selecting the panel data estimation model which will be used, whether the Common Effect, Fixed Effect, or Random Effect, we performed the three tests, namely the Chow Test, Hausman Test, and Lagrange Multiplier test (LM). After determining the right model for panel data estimation, we performed the classic assumption tests consisting of the normality test, heteroscedasticity test, and multicollinearity test. Thus, we could ensure that the data, variables, and models to be estimated are according to their designations. In the hypothesis testing, F-test, ttest, and the coefficient of determination are used to answer the relationship and effect of the independent variables on the dependent variable.

The econometric equation with the panel data regression method used in this study is prepared to answer all of the proposed problem formulations. The first problem formulation is whether there is an influence of income, consumption, savings, and the number of ZMO on the zakat fund collection. The second problem 
Jurnal Bisnis dan Manajemen, Volume 21, No. 2, September 2020, p. 156-165

formulation is whether there is an effect of each income, consumption, and savings and the number of MZO on zakat fund collection in West Java each year. Here is the econometric model of this study:

Yit $=\alpha+\beta 1 X 1$ it $+\beta 2$ X2it $+\beta 3$ X3it $+\beta 4$ X4it + eit or

ZAKATit $=\alpha+\beta 1 I N C O 1 t+\beta 2 C O N S 2 i t+$

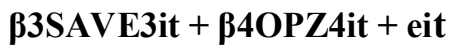

Where:

$\mathrm{Y}=$ zakat fund collection

$\mathrm{X} 1$ = average income

$\mathrm{X} 2$ = average consumption expenditure

$\mathrm{X} 3=$ the amount of savings

$\mathrm{X} 4=$ number of $\mathrm{ZMO}$ in all cities

\section{RESULTS AND DISCUSSION}

Based on the results of the Hausman Test and the Lagrange Multiplier Test, the Random Effect model is the best model for estimating the results of Regression Analysis (shown in Table 1).

\section{Table 1. Model Determination Test Results}

\begin{tabular}{|c|c|c|c|}
\hline No. & Test & $\begin{array}{l}\text { Result } \\
\text { (Prob.) }\end{array}$ & Conclusion \\
\hline 1. & Chow & $\begin{array}{l}0.000 \\
0.000\end{array}$ & $\begin{array}{l}\text { The best model to use is } \\
\text { Fixed Effect. }\end{array}$ \\
\hline 2. & Hausman & 0.8981 & $\begin{array}{l}\text { The best model to use is } \\
\text { Random Effect. }\end{array}$ \\
\hline 3. & $\begin{array}{l}\text { Lagrange } \\
\text { Multiplier }\end{array}$ & 0.000 & $\begin{array}{l}\text { The best model to use is } \\
\text { Random Effect. }\end{array}$ \\
\hline
\end{tabular}

Source: Data processing results

Furthermore, based on the regression results using the Random Effect model, as shown in Table 2, the econometric equation is obtained as follows:
ZAKATit $=4.480 .000 .000+53.46920 I N C O 1 t+$

198.2764CONS2it - 5.239868SAVE3it +

2.060.000.000OPZ4it

Table 2. Regression Result of Model Random Effect

\begin{tabular}{|c|c|c|c|c|}
\hline Variable & Coefficient & $\begin{array}{l}\text { Std. } \\
\text { Error }\end{array}$ & t-Stat & Prob. \\
\hline $\mathrm{C}$ & $4.48 \mathrm{E}+08$ & $5.49 \mathrm{E}+08$ & 0.815437 & 0.4161 \\
\hline $\mathrm{X} 1$ & 53.46920 & 22.03820 & 2.426205 & 0.0165 \\
\hline $\mathrm{X} 2$ & 198.2764 & 29.47008 & 6.728056 & 0.0000 \\
\hline $\mathrm{X} 3$ & -5.239868 & 25.12351 & - & 0.8351 \\
\hline $\mathrm{X} 4$ & $2.06 \mathrm{E}+08$ & $1.05 \mathrm{E}+08$ & 1.956690 & 0.0503 \\
\hline \multicolumn{2}{|c|}{ R-squared } & 0.461526 & $\begin{array}{l}\text { Mean } \\
\text { dependent } \\
\text { var }\end{array}$ & $3.61 \mathrm{E}+08$ \\
\hline $\begin{array}{l}\text { Adjusted } \\
\text { squared }\end{array}$ & $\mathrm{R}-$ & 0.446973 & $\begin{array}{l}\text { S.D } \\
\text { dependent } \\
\text { var }\end{array}$ & $1.477 \mathrm{E}+09$ \\
\hline \multicolumn{2}{|c|}{ regression } & $1.09 \mathrm{E}+09$ & $\begin{array}{l}\text { Sum squared } \\
\text { resid }\end{array}$ & $1.77 \mathrm{E}+20$ \\
\hline \multicolumn{2}{|c|}{ F-statistic } & 31.71274 & $\begin{array}{l}\text { Durbin- } \\
\text { Watson stat }\end{array}$ & 0.457669 \\
\hline \multicolumn{2}{|l|}{$\begin{array}{l}\text { Prob(F- } \\
\text { statistic) }\end{array}$} & \multicolumn{2}{|l|}{0.000000} & \\
\hline
\end{tabular}

Source: Data processing results

The value of each variable from the results of the Random Effect model regression can be interpreted as follows:

- The value of $4,480,000,000$ means that without being influenced by any variable under this study, an increase in zakat funds is Rp. 4,480,000,000 or 4.5 billion rupiahs

- The value of 53,46920 INCO means that if income increases by one million rupiahs, the zakat fund collection will increase positively by 53 million rupiahs

- The value of 198.2764 CONS means that if the consumption expenditure increases by one million rupiahs, the zakat fund collection will increase by 198 million rupiahs

- The value of -5.239868 SAVE means that if the saving increases by one billion rupiahs, 
Jurnal Bisnis dan Manajemen, Volume 21, No. 2, September 2020, p. 156-165

the zakat fund collection will decline by 5.24

billion rupiahs

- The value of $2,060,000,000 \mathrm{OPZ}$ means that if the number of ZMO in an area increases by one unit, the zakat fund collection will increase by 2.06 billion rupiahs.

From the above explanation about the regression results using the Random Effect model, it can be seen that income, consumption, savings, and OPZ aggregately influence zakat. Saving is the only variable which has a negative effect on zakat as the dependent variable.

Furthermore, to determine the effect of income, consumption, savings, and the amount of ZMO on the zakat fund collection, we performed several tests to prove the significance or influence between the independent variable and the dependent variable. They are as follows.

Table 3. The F-Test (simultaneous) of Random Effect Model

\begin{tabular}{lll}
\hline Model & F-stat & Prob. F-stat \\
\hline Regression & 31.71274 & 0.00000 \\
\hline
\end{tabular}

Source: Data processing results

The results of the F-Test (shown in Table 3) indicate that the value of Prob. F-stat is 0.0000 , which is less than the significance level of 0.05 . It means that simultaneously, the four independent variables, namely income, consumption, savings, and the number of $\mathrm{ZMO}$ have a significant effect on the dependent variable.
Table 4. The T-Test (partial) of the Random Effect Model

\begin{tabular}{lll}
\hline Variable & Coefficient & Prob. \\
\hline INCO (X1) & 53.46920 & 0.0165 \\
CONS (X2) & 198.2764 & 0.0000 \\
SAVE (X3) & -5.239868 & 0.8351 \\
OPZ (X4) & $2.06 \mathrm{E}+08$ & 0.0503 \\
\hline
\end{tabular}

Source: Data processing results

Based on the results of the t-test, shown in Table 4, we found that there are three independent variables that have the Prob. values below 0.05 . It means those three variables, namely, income, consumption, and the number of ZMO, significantly influence the zakat fund collection.

Additionally, from the determination coefficient (shown in Table 5), we found that income, consumption, savings, and the number of ZMO simultaneously affect the zakat fund collection by $46 \%$. Other factors outside this study influence the rest of the zakat fund collection.

Table 5. Results of the Determination Coefficient of the Random Effect Model

\begin{tabular}{ccc}
\hline Model & R-squared & $\begin{array}{c}\text { Adjusted R- } \\
\text { squared }\end{array}$ \\
\hline Regression & 0.461526 & 0.446973 \\
\hline
\end{tabular}

Source: Data processing results

Based on the Random Effect model regarding the effect of income, consumption, savings, and the number of ZMO on the zakat fund collection in all cities in West Java in 2001 - 2017, we can conclude that the income and consumption of the average community positively and significantly affect the zakat fund collection if the income and consumption 
Jurnal Bisnis dan Manajemen, Volume 21, No. 2, September 2020, p. 156-165

increase, the zakat fund collection will also increase.

Increasing consumption affects the increasing zakat collected. It means that the greater the consumption is, the larger the amount of income incurred by the obligatory zakat. In other words, zakat can be considered as part of the consumption itself. This is because paying zakat is part of the primary worship, which also fulfills the spiritual needs of the payer. It can be understood why the increase in the level of savings does not have a significant effect. This effect on zakat fund collection is also negative, different from the other three variables under this study. There are many zakat payers who still do not realize their obligation for paying zakat, and saving itself is one of the objects of zakat (Azman \& Bidin, 2015).

The growth in the number of ZMO also positively have big affects the zakat fund collection. In addition to collecting zakat, ZMOs distribute it used s for cost financing for business capital, investment, and community consumption, which ultimately encourages economic growth (Suprayitno, 2018).

The enormous potential of zakat cannot be maximized yet. It is necessary to start looking for other ways to increase the collection of zakat funds. Regulators can set a salary deduction policy of $2.5 \%$ per month or create a particular zakat account, which will be taken annually by formal zakat institutions collaborating with particular companies. The increase in income has proven to affect the zakat fund collection.

The ZMOs in all cities of West Java can also be made effective by increasing public interest and knowledge about them through the Community Based Development and the synergy between the poverty alleviation program by the local government with the poor society empowerment program by ZMOs (Hayati \& Caniago, 2012). ZMOs can also collaborate with companies in collecting zakat funds from their employees.

Public consumption behavior can also be exploited by ZMOs by offering their zakat products that will benefit the mustahiq. Thus, zakat will be perceived as the needed instrument, not merely the religious obligation.

Moreover, ZMOs can now more easily reach their market by utilizing technology or fintech. The use of technology is essential because it will build trust in ZMOs. People will have the opportunity to track and monitor the process of collection and disbursement of zakat. Furthermore, annual reports explain details and show where and how zakat was spent (Migdad, 2019).

The parties participating in maximizing zakat potential are not only the ZMOs, but also the regulators, namely the government bodies (the Ministry of Religion and BAZNAS). The public must also learn about how to pay zakat through ZMOs and find official zakat institutions 
Jurnal Bisnis dan Manajemen, Volume 21, No. 2, September 2020, p. 156-165

nearby since zakat is an obligation for every

Muslim, both zakat al-maal and zakat al-fitr.

\section{CONCLUSION}

This research found that collectively, income, saving, consumption, and numbers of ZMO affect zakat collection in West Java. The most influential factor in maximizing zakat potential is the existence of ZMOs. There are still negative perceptions of how ZMOs in managing zakat. However, public trust gradually increases due to the application of information technology by the ZMOs. It makes the zakat management by ZMOs more transparent and more comfortable to monitor by the public.

The next factor is that the increase in consumption increases the potential for zakat collection. Zakat is distributed for stimulating consumption. Thus, zakat becomes part of the consumption offered by ZMOs to mustahiq. Furthermore, we conclude that the increase in income will also increase the potential for zakat collection, while saving is not a factor that encourages zakat collection.

\section{REFERENCES}

Aziz, M.R.A.B. \& Anim, N.A.H.M. (2020). Trust Towards Zakat Institutions Among Muslims Business Owners. Jurnal Ekonomi \& Keuangan Islam, 6(1), 1-9.

Azman, F.M.N \& Bidin, Z. (2015). Factors Influencing Zakat Compliance Behavior on Saving. International Journal of Business and Social Research, 5(1).

Daulay. AH \& Lubis. I. (2015) Analisis Faktor-Faktor Penyebab Keengganan Masyakarat Membayar
Zakat Melalui Instansi BAZIS/LAZ di Kota Medan. Jurnal Ekonomi dan Keuangan, 3(4).

BAZNAS. (2018). Statistik Zakat Nasional 2017. Baznas. Bagian Liaison dan Pelaporan.

BAZNAS. (2019). Pengaruh Zakat Terhadap Perekonomian Makro Indonesia. Pusat Kajian Strategis Badan Amil Zakat Nasional (BAZNAS) Republik Indonesia. No.23/ON/12/2019, 2 Desember 2019.

BPS. (2018). Provinsi Jawa Barat Dalam Angka. BPS Provinsi Jawa Barat, 721. https://doi.org/32560.1802.

Canggih, C., Fikriyah, K., \& Yasin, A. (2017). Potensi Dan Realisasi Dana Zakat Indonesia. Al-Uqud: Journal of Islamic Economics, 1(1), 14. https://doi.org/10.26740/jie.v1n1.p14-26.

Fitriyah, I. (2017). Faktor-Faktor Yang Mempengaruhi Pembayaran Zakat, Studi Kasus Masyarakat Sekitar Majlis Dzikir Wa Ta'lim Mihrobul Muhibbin. Skripsi. Jurusan Ekonomi Syariah Fakultas Ekonomi Dan Bisnis, Uin Syarif Hidayatullah Jakarta.

Hakim, I. (2016). Diversifikasi Penghasilan Kontemporer Sebagai Alternatif Sumber Dana Zakat. Falah: Jurnal Ekonomi Syariah. ISSN 2502-7824. Vol 1 No 1, 103-112. DOI: 10.22219/jes.v1i1.2701.

Senadjki, A., Nachef, T. \& Rusli, N. (2015). The Impact of Zakat on Income Inequality and Poverty in Malaysia: A Panel Data Analysis. Market Forces; College of Management Sciences. ISSN ISSN: 2309-866X, 10 (1).

Hayati, K. \& Caniago, I. (2012). Model Of Poor Society Empowerment Through Optimizing The Potential Of Zakat: A Case Study in Lampung Province. Journal of Indonesian Economy and Business. 27 (2), $174-191$.

Kuncoro, M. (2011). Metode Kuantitatif. Yogyakarta: Sekolah Tinggi Ilmu Manajemen: YKPN.

Kusmanto, A. (2014). Peran Lembaga Amil Zakat Nasional Dalam Penghimpunan Dana Zakat, Infaq, dan Shodaqoh. Pandecta: Research Law Journal. 9(2), 292. https://doi.org/10.15294/pandecta.v9i2.3581.

Manurung, S. (2013). Islamic Religiosity And Development Of Zakat Institution. Qijis; Qudus International Journal of Islamic Studies. Volume Number 2 | July-December 2013.

Migdad, A. (2019). Managing Zakat through Institutions: Case of Malaysia. International Journal of Islamic Economics and Finance Studies, 2019/3: 28-44. DOI: 10.25272/ijisef.519228. 
Jurnal Bisnis dan Manajemen, Volume 21, No. 2, September 2020, p. 156-165

Mubarok, A., \& Fanani, B. (2014). Penghimpunan Dana Zakat Nasional (Potensi, Realisasi dan Peran Organisasi Pengelola Zakat). PERMANA. 5(2) Februari 2014. 7-16.

MUI. (2003). Fatwa MUI No 3 Tahun 2003: Zakat Penghasilan.

Nachrowi, N., \& Usman, H. (2006). Pendekatan Populer dan Praktis Ekonometrika untuk Analisis Ekonomi dan Keuangan. Jakarta: Lembaga Penerbit FE UI.

Noviarita, H. (2015). Telaah Kritis Zakat Dalam Perspektif Makro Ekonomi. 1-25 Academia Edu. Retrieved from https://www.academia.edu/37688887/TELAAH_ KRITIS_ZAKAT_DALAM_PERSPEKTIF_MĀ KRO_EKONOMI_Heni_Noviarita.

Nurulliah, N. (2017). Potensi Zakat di Jawa Barat Mencapai Trilliunan Rupiah. PikiranRakyat.com. Retrieved from https://www.pikiranrakyat.com/jawa-barat/pr-01281514/potensi-

zakat-di-jawa-barat-mencapai-trilliunan-rupiah403106.

Pangestika, S. (2015). Analisis estimasi model regresi data panel dengan pendekatan common effect model (cem), fixed effect model (fem), dan random effect model (rem). Skripsi. Jurusan Matematika Fakultas Matematika Dan Ilmu Pengetahuan Alam. Universitas Negeri Semarang.

Persaulian, B., Aimon;, H., \& Anis, A. (2013). ANALISIS KONSUMSI MASYARAKAT DI INDONESIA. Jurnal Kajian Ekonomi, 1(2), I(02), 1-23. Retrieved from https://media.neliti.com/media/publications/7109ID-analisis-konsumsi-masyarakat-diindonesia.pdf.

Saubani, A. (2018). Kemenag: Potensi Zakat Nasional Capai Rp 217 Triliun. Republika.co.id. Retrieved from https://www.republika.co.id/berita/duniaislam/islam-nusantara/18/02/23/p4m1gs409kemenag-potensi-zakat-nasional-capai-rp-217triliun.

Sugiyono. (2018). Metode Penelitian Kuantitatif, kualitatif dan $R \& D$. Bandung: Alfabeta.

Suprayitno, E. (2018). Zakat and SDGs : The Impact of Zakat on Economic Growth, Consumption and Investment in Malaysia. Advances in Economics, Business and Management Research, volume 101. 1st International Conference on Islamic Economics and Business (ICONIES 2018).

Widarjono, A. (2007). Ekonometrika Teori dan Aplikasi untuk Ekonomi dan Bisnis. Yogyakarta: FE UII. 